The Destruction and Recovery of Monte Cassino, 529-1964 


\section{Italy in Late Antiquity and the Early Middle Ages}




\section{The Destruction and Recovery of Monte Cassino, 529-1964}

Kriston R. Rennie 
Cover illustration: Succisa Virescit [Montecassino Triptych], 1946. By Jan Henryk de Rosen (1891-1982). Wax tempera and gold leaf on panel, $64 \times 1201 / 4$ inches (open), $64 \times 60$ inches (closed). Saint Vincent Archabbey Collection, Latrobe: Pennsylvania. Photo: Richard Stoner.

Cover design: Coördesign, Leiden

Lay-out: Crius Group, Hulshout

$\begin{array}{ll}\text { ISBN } & 978 \text { 94 6372 913 0 } \\ \text { e-ISBN } & 978 \text { 90 4855212 2 } \\ \text { DOI } & 10.5117 / 9789463729130 \\ \text { NUR } & 684\end{array}$

(c) K.R. Rennie / Amsterdam University Press B.V., Amsterdam 2021

All rights reserved. Without limiting the rights under copyright reserved above, no part of this book may be reproduced, stored in or introduced into a retrieval system, or transmitted, in any form or by any means (electronic, mechanical, photocopying, recording or otherwise) without the written permission of both the copyright owner and the author of the book.

Every effort has been made to obtain permission to use all copyrighted illustrations reproduced in this book. Nonetheless, whosoever believes to have rights to this material is advised to contact the publisher. 
And there, uplifted, like a passing cloud That pauses on a mountain summit high, Monte Cassino's convent rears its proud And venerable walls against the sky. - Henry Wadsworth Longfellow ${ }^{1}$ 
